\title{
Assessment on the level of contamination of Turag river at Tongi area in Dhaka
}

\author{
K. S. Ahmed ${ }^{1,2 *}$, A. K. M. L. Rahman 1 , M. Sarkar ${ }^{1}$, J. B. Islam ${ }^{1}$, I. A. Jahan², M. Moniruzzaman', \\ B. Saha ${ }^{2}$ and N. C. Bhoumik ${ }^{3}$
}

${ }^{1}$ Department of Chemistry, Jagannath University, Dhaka 1100, Bangladesh.

${ }^{2}$ Bangladesh Council of Scientific and Industrial Research (BCSIR), Dhaka 1205, Bangladesh

${ }^{3}$ Wazed Miah Science Research Centre, Jahangirnagar University, Dhaka-1342, Bangladesh

\begin{abstract}
Assessment on the level of pollution of Turag river water was performed by measuring various physico-chemical parameters. Water samples were collected five times in a year both dry and rainy season at five different locations: Bishwa Ijtema field, Tongi Bridge, Kachare ghate, River side of Dhaka Dying and Effluent of Dhaka Dying. Most of the measured parameters exceeded the permissible limit of standard level. Values for different parameters at different points were recorded such as Temperature (T): 23.9 to $31.2^{\circ} \mathrm{C}, \mathrm{pH}: 7.2$ to 10.1 , Salinity: 64 to 933 ppm, Total dissolved solid (TDS): 90 to 1244 ppm, Electrical Conductivity (EC): 135 to $1856 \mu$ s/cm, Dissolve oxygen (DO): 0.5 to $3.6 \mathrm{mg} / \mathrm{L}$ and Chemical oxygen demand (COD): 220 to $1170 \mathrm{mg} / \mathrm{L}$. The concentration (ppm) of heavy metals were also observed such as Chromium (Cr) 0.0339 to 0.6334 , Cadmium (Cd) 0.0068 to 0.0170 , Nickel (Ni) 0.1282 to 0.6207 , Cooper (Cu) 0.0148 to 0.1703 and Zink (Zn) 0.0366 to 0.1890 at dry season. The values of different parameters determined are above the safe limits recommended by DoE, EQS and WHO. Therefore, it can be concluded that water relieved from selected locations were not suitable for human consumption during the period of experiments.
\end{abstract}

Keywords: Turag River water; Water quality parameters; Dhaka Dying Effluent; Heavy metals; Level of toxicity

\section{Introduction}

Water is the most essential component in the universe and has a strong correlation between water and all kinds of life to sustain. Despite its importance, water is the most poorly managed resource in the developing countries (Fakayode, 2005). Presently, $10 \%$ of waste water generated is being treated; the rest is directly discharged into the water bodies without treatment (Satter and Islam, 2005). Water also known as blue gold, one of the most priceless gifts of Nature is also regarded as the life line on Earth, because evolution of life and development of human civilization could not have been possible without water. Rivers are the important surface water sources and are being used for various purposes viz; drinking, household, irrigation, industrial purposes and recreation (Islam et al., 2015). All recognized civilizations in the world evolved around the rivers (Madhuri et al., 2004, Balasankar and Nagarajan, 2000). Dhaka, the capital and most populated city in Bangladesh is now a member of mega city family in the world. Rapid and unplanned urbanization, commercial development along with population pressure have made a severe environmentally polluted city in the world (Haigh, 2004, Sarkar et al., 2015, Karn and Harada, 2001). The Turag River, running by the side of the Dhaka City, is one of the most polluted rivers in Bangladesh. Many industries have been grown up in the bank of Turag River during last decade and the numbers of new industries are continually increasing (DoE, 1997). Tongi area situated in the Bank of Turag River is primarily known and developed as industrial zone according to the Bangladesh Master Plan of 1959. Various categories of industries include metal industries, garments, jute, textile, spinning, pharmaceutical, food manufacturing industry, lot of tanneries, chemical factories etc. are available in Tongi area (RAJUK, 2010, Rahman et al., 2012). Most of the industries discharge their effluents directly or indirectly into the Turag River without any treatment causing pollution of the surface water. Moreover, many sewerage and municipal sewage drainage system have become a dumping ground of all kinds of solid, liquid and chemical waste that polluting the Turag River (Rahman et al., 2012). As a result, complex mixture of hazardous chemicals, both organic and inorganic are released

*Corresponding author. e-mail: shahinjnu005@gmail.com 
into the Turag water resulting in different chemical and biochemical interactions occurring in the river system and thus severely deteriorate the water quality. Heavy metals such as $\mathrm{Cu}, \mathrm{Zn}, \mathrm{Cr}, \mathrm{Ni}, \mathrm{Cd}$ etc. are present in the river water as trace amount, but have detrimental effect on water environment and thus on human existence (ACME, 2004). Contamination by the heavy metals declines the water quality i.e. change the water properties such as $\mathrm{pH}, \mathrm{EC}$, TDS etc. and alter natural processes and natural resource communities, unabated degradation of the aquatic environment poses consequences

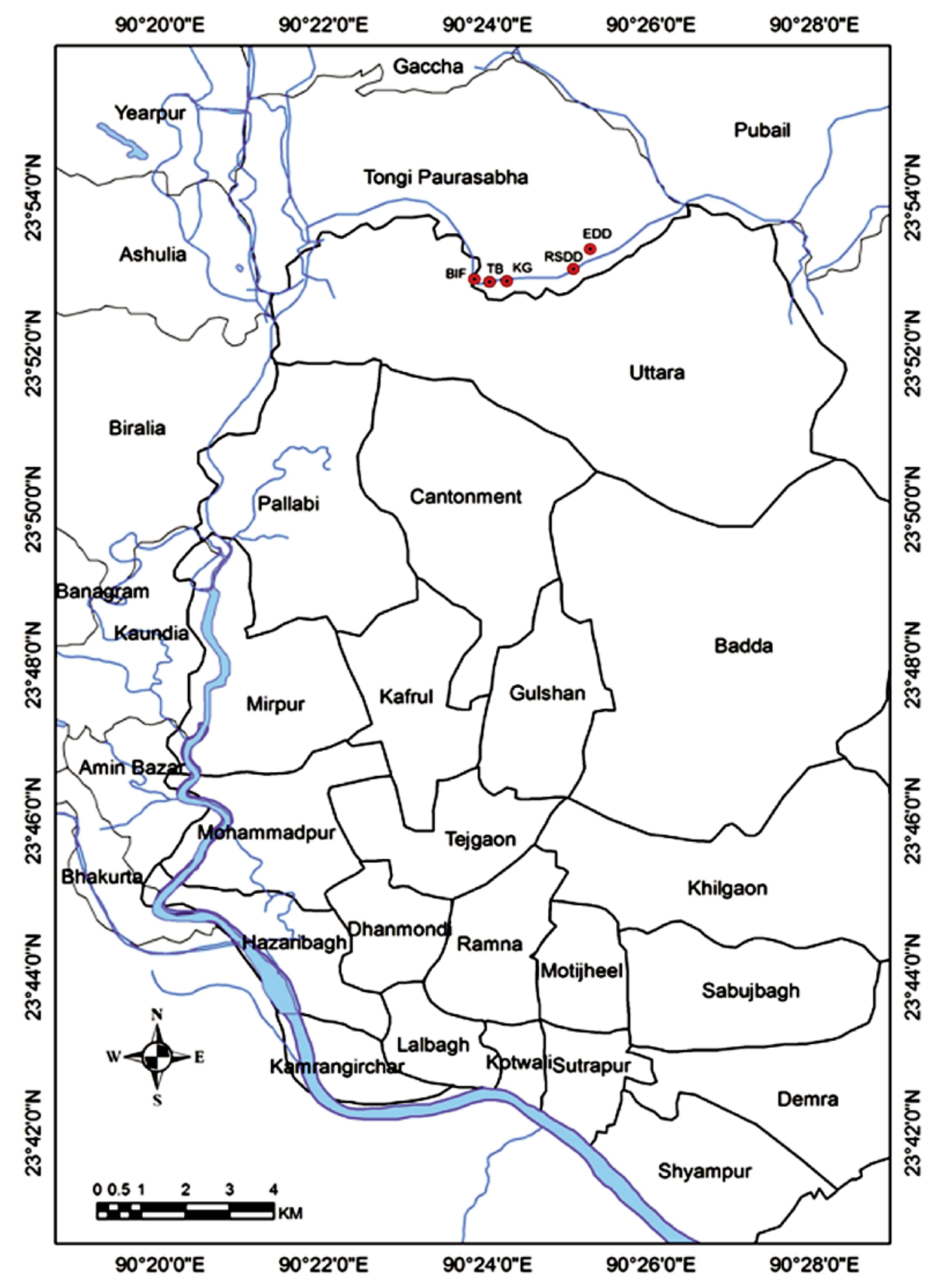

Fig. 1. Study area of the present work 
for fishery resources and their habitats. Exposure to heavy metals has linked several human diseases such as development retardation or malformation, Kidney damage, Cancer, abortion, effect on intelligence and behavior, and even death in some cases of exposure to very high concentration. The symptoms of toxic heavy metal poisoning are very similar to autism, PDD, Aspergers, \& ADD/ ADHD (Ghrefat and Yusuf, 2006; Batteiro et al., 2010). The monitoring of surface water plays an important role for assessing water quality, hydrochemistry and ecology and also very much essential for safe and sound environment and ecosystem (Sarkar et al., 2015, Islam et al., 2015). Considering the different sources of pollution near Turag River we aimed to study the water quality and the level of toxicity through heavy metals such as $\mathrm{Cr}, \mathrm{Cd}, \mathrm{Ni}, \mathrm{Cu}$, and $\mathrm{Zn}$ were measured at different locations of Turag River and Dhaka Dying Effluent (a dying industry situated on the bank of Turag River).

\section{Materials and methods}

Study area

Assessment of contamination on river water and industrial effluent were performed from December 2012 to August 2013. Water samples were collected near Bishwa Ijtema Field (B.I.F), Tongi Bridge (T.B), Kachari Ghate (K.G), River side of Dhaka Dying (R.S.D.D) and Effluent of Dhaka Dying (E.D.D) are shown in Fig. 1. Bishwa Ijtema field which receives various kinds of wastes. Pilgrims staying at the riverside for 6 to 8 days without proper sanitation system contribute to the pollution at the Bishwa Ijtema side of the Turag River. Second Sampling site was Tongi Bridge which also polluted by sanitation system, municipal west and various Industries. Third Sampling site was Kachari Ghate which polluted by Paper industries and municipal sewage drainage. The highest polluted sampling sides were river side of Dhaka Dying and Effluent of Dhaka Dying which polluted by various chemical used in Dying industry.

\section{Sample collection and analysis}

Samples were collected by using plastic bottles of $500 \mathrm{~mL}$. Before sample collection, bottles were cleaned by detergent and then it was treated with $5 \% \mathrm{HNO}_{3}$ acid overnight and finally washed with de-ionized water followed by repeated washing with sample water so as to avoid contamination. All the samples were taken with grab sampling. After sampling, the bottles were kept in air tight and labeled correctly for identification. The parameters, $\mathrm{pH}$ was measured using Twin pH meter (B-211, Horiba, Japan), DO was measured using Dissolved Oxygen meter (YK-22 DO meter, Taiwan). TDS, salinity, conductivity and temperature were measured by instrumentally using multimeter (CTS-406K, Taiwan). COD were measured by titrimetric method using $\mathrm{K}_{2} \mathrm{Cr}_{2} \mathrm{O}_{7}$ as oxidizing agent. Concentration of heavy metals such as $\mathrm{Cr}, \mathrm{Cd}$, $\mathrm{Ni}, \mathrm{Cu}$, and $\mathrm{Zn}$ in the River water and industrial Effluent were determined by using atomic absorption spectrophotometer (AAS Shamizu 7000) using standard analytical method. Correlations of parameters were done using Minitab V-13.0 software.

\section{Results and discussion}

The outcome of physicochemical parameters and concentration of heavy metals at five different points of the Turag river are presented and discussed below.

\section{Temperature (T)}

Temperature of water may not be as important in pure water because of the wide range of temperature tolerance in aquatic life, but in polluted water, temperature can have profound effect on dissolve oxygen (DO). The fluctuation in river water temperature usually depends on the season, geographic location, sampling time and temperature of Effluents entering the stream (Ahipathi and Puttaiah, 2006). In this study, the temperature in Turag River water is in the range of

Table I. Location of water samples collection

\begin{tabular}{clcc}
\hline Station No. & Name of Location & Longitude & Latitute \\
\hline 1 & Bishwa Ijtema Field (B.I.F) & $90^{\circ} 23^{\prime} 37.4568^{\prime \prime} \mathrm{E}$ & $23^{\circ} 52^{\prime} 50.9340^{\prime \prime} \mathrm{N}$ \\
2 & Tongi Brize (T.B) & $90^{\circ} 24^{\prime} 1.4796^{\prime \prime} \mathrm{E}$ & $23^{\circ} 52^{\prime} 55.0308^{\prime \prime} \mathrm{N}$ \\
3 & Kachari Ghate (K.G) & $90^{\circ} 24^{\prime} 13.8744 " \mathrm{E}$ & $23^{\circ} 52^{\prime} 55.8516^{\prime \prime} \mathrm{N}$ \\
4 & River side of Dhaka Dying (R.S.D.D) & $90^{\circ} 25^{\prime} 1.5636^{\prime \prime} \mathrm{E}$ & $23^{\circ} 53^{\prime} 11.6124^{\prime \prime} \mathrm{N}$ \\
5 & Effluent of Dhaka Dying (E.D.D) & $90^{\circ} 25^{\prime} 2.0068^{\prime \prime} \mathrm{E}$ & $2^{\circ} 53^{\prime} 10.9320^{\prime \prime} \mathrm{N}$ \\
\hline
\end{tabular}


23.9 to $31.2^{\circ} \mathrm{C}$ and Effluent of Dhaka Dying which is 24.9 to $31.1^{\circ} \mathrm{C}$ from December 2012 to August 2013. The high temperature is observed in wet season than dry season in both Turag River water and Effluent of Dhaka Dying. The correlation of temperature $(\mathrm{T})$ with other parameters is shown in Table II. In this Table T and DO are positively correlated but other parameter such as pH, salinity, TDS, EC and COD are negatively correlated. The Correlation of $\mathrm{T}$ with $\mathrm{pH}$, salinity, TDS, EC, DO and COD (P value 0.638, 0.232, 0.213, 0.238, 0.000 and 0.000 ) are insignificant. permissible limit for diverse uses like irrigation, domestic and recreational, according to standard value of Department of Environment (DoE) (pH 6 to 9) but in the Effluent of Dhaka Dying it is out of range of the standard value of DoE (pH 6 to 9). From the Fig. 2 it is found that pH value is higher in the effluent almost all over the year than River water; this is because Dhaka Dying uses various toxic substances. As a result $\mathrm{pH}$ value in Turag river water increased day by day. The $\mathrm{pH}$ significantly affects biological activities. It also affects some properties of water body, activity

Table II. Correlation chart between physiochemical parameter in Turag river water and Effluent of Dhaka Dying

\begin{tabular}{|c|c|c|c|c|c|c|c|}
\hline Temp. & $\mathrm{pH}$ & Salinity & TDS & $\mathrm{EC}$ & DO & COD & Temp. \\
\hline & 1 & & & & & & \\
\hline $\mathrm{pH}$ & -0.099 & 1 & & & & & \\
\hline Salinity & -0.248 & 0.421 & 1 & & & & \\
\hline TDS & -0.258 & 0.424 & 0.999 & 1 & & & \\
\hline $\mathrm{EC}$ & -0.245 & 0.413 & 1.000 & 0.999 & 1 & & \\
\hline DO & 0.888 & -0.288 & -0.591 & -0.604 & -0.589 & 1 & \\
\hline COD & -0.887 & 0.222 & 0.587 & 0.602 & 0.587 & -0.983 & 1 \\
\hline
\end{tabular}

$p H$

Fig. 2. shows the $\mathrm{pH}$ value against seasonal variation at different selected places of Turag River water. $\mathrm{pH}$ value ranged from 7.2 to 8.0 for river water and from 7.5 to 10.1 for industrial Effluent. The value for River water is within the of organism and efficiency of toxic substances present in the aquatic environment. The correlation of $\mathrm{pH}$ with other parameters is shown in Table II. In this Table correlation of $\mathrm{pH}$ with Salinity, TDS, EC and COD are positively correlated but DO is negatively correlated. The correlation of $\mathrm{pH}$ with Salinity, TDS and EC (P value $0.036,0.035$ and

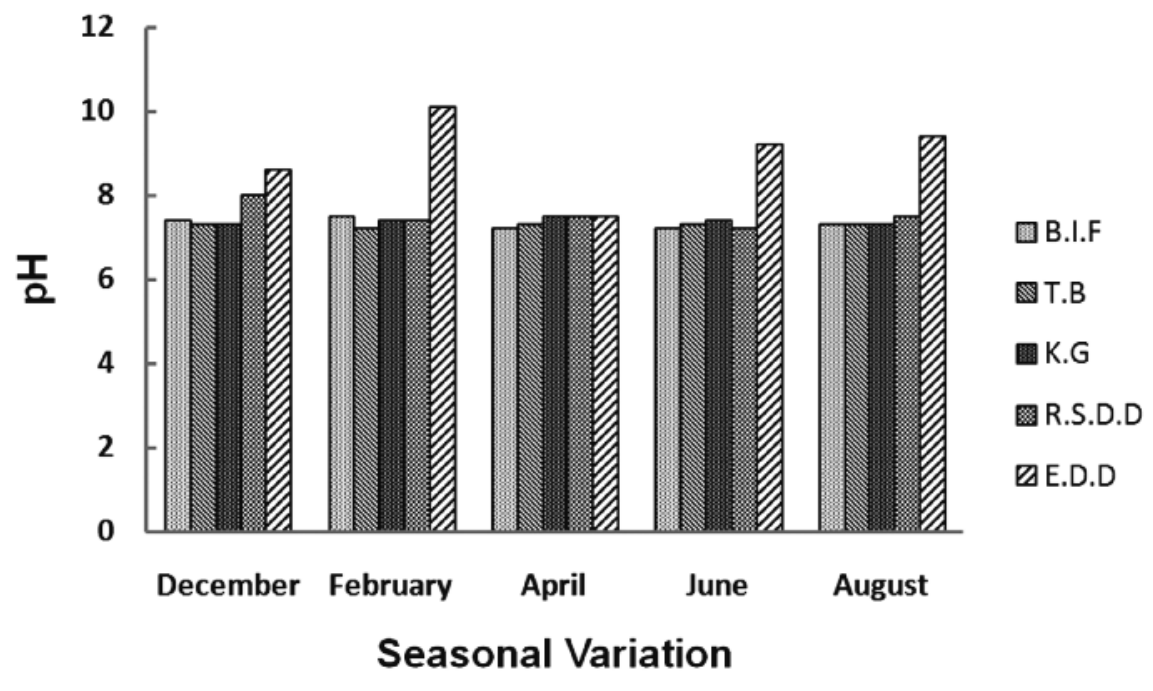

Fig. 2. pH variation in the Turag River water and the Effluent of Dhaka Dying 
0.040) are shown significant but other parameters such as DO and COD (P value 0.162 and 0.285 ) are shown insignificant.

\section{Salinity}

Salinity is an important property for the inland water body and natural water. It is originally conceived as a measure of mass of dissolved salt in a given mass of solution (Clesceri et al., 1998). Salinity is the measure of salt present in the water body. It measures how much salt is in the water. In the Turag River water salinity varies from 64 to $585 \mathrm{ppm}$ whereas the Effluent of Dhaka Dying ranged from 231 to $933 \mathrm{ppm}$. The highest and lowest salinity value of both sampling side (river water and effluent) are observed in February and August, respectively. In February various industries such as lather industry, textile industries etc. use salt in their production processes and discharge effluents contain salts. As a result river water becomes salty and create hazardous situation for fresh water loving biota. That's why in February the salinity is higher. Salinity has good relation with TDS and EC. Salinity value increased with increasing TDS and EC. The correlation of salinity with other parameters is shown in Table II. In these Table correlation of salinity with EC, TDS and COD are positively correlated but DO is negatively correlated. The correlation of salinity with DO and COD (P value 0.002 and 0.002 ) are significant but TDS and EC (P value 0.000 and 0.000 ) are insignificant.

\section{Total dissolved solids (TDS)}

The Total Dissolved Solids (TDS) mainly indicate the presence of various kinds of minerals and metallic ions which are comprised both colloidal and dissolved solids in water. It is also an important chemical parameter for quality water (Kabir et al., 2002). TDS observed from 90 to 795 ppm for river water and 332 to 1244 ppm for the Effluent of Dhaka Dying. Higher TDS value was measured in Dhaka Dying Effluent than the river water. The TDS attained to its maximum value in February and the lowest value found in August. High TDS detected could be attributed to the various Dying stuffs being used in the textile mills and they might be major sources of the heavy metals. It is reported that the increase of heavy metal concentrations in the river sediment could increase suspended solids concentrations (Kambole, 2003). The correlation of TDS with other parameters is shown in Table II. In this Table correlation of TDS with EC and COD are positive whereas with DO it is negative. The Correlation of TDS with DO and COD (P value 0.001 and 0.001 ) are significant but EC (P value 0.000$)$ is insignificant.

\section{Electrical conductivity (EC)}

The electrical conductivity (EC) is usually used for representing the total concentration of ionic species in water. EC variation was found from 135 to $1194 \mu \mathrm{s} / \mathrm{cm}$ for river water and 483 to $1856 \mu \mathrm{s} / \mathrm{cm}$ for the Effluent of Dhaka Dying. The

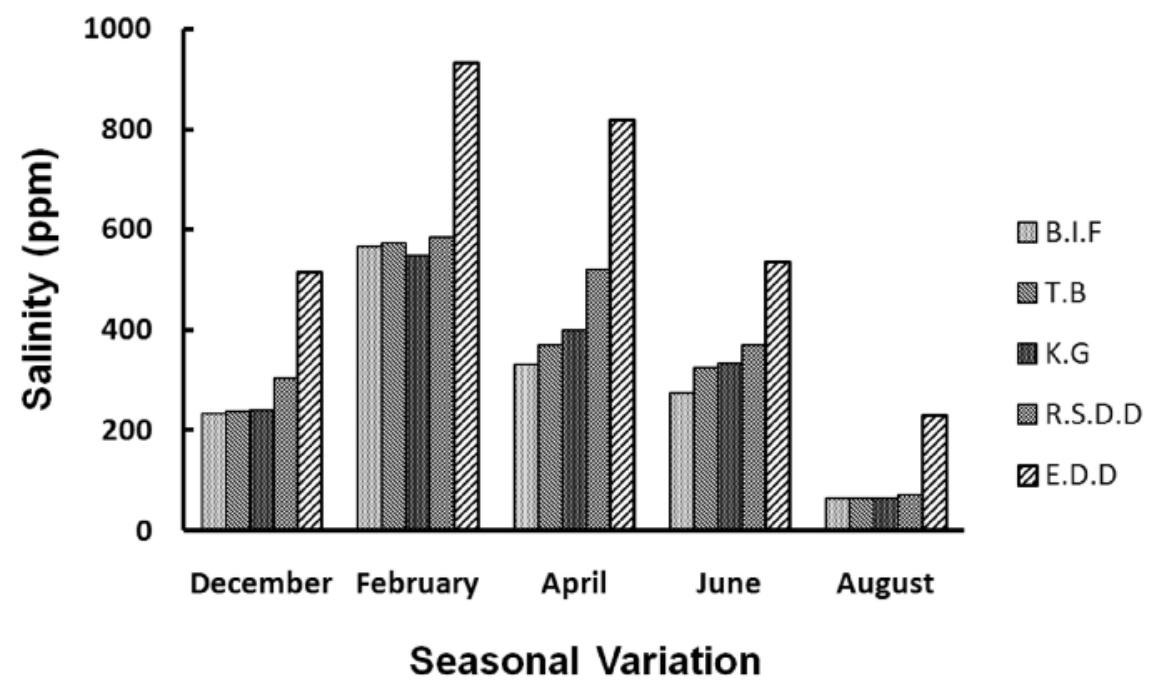

Fig. 3. Seasonal variation of salinity in the Turag river water and the Effluent of Dhaka Dying 


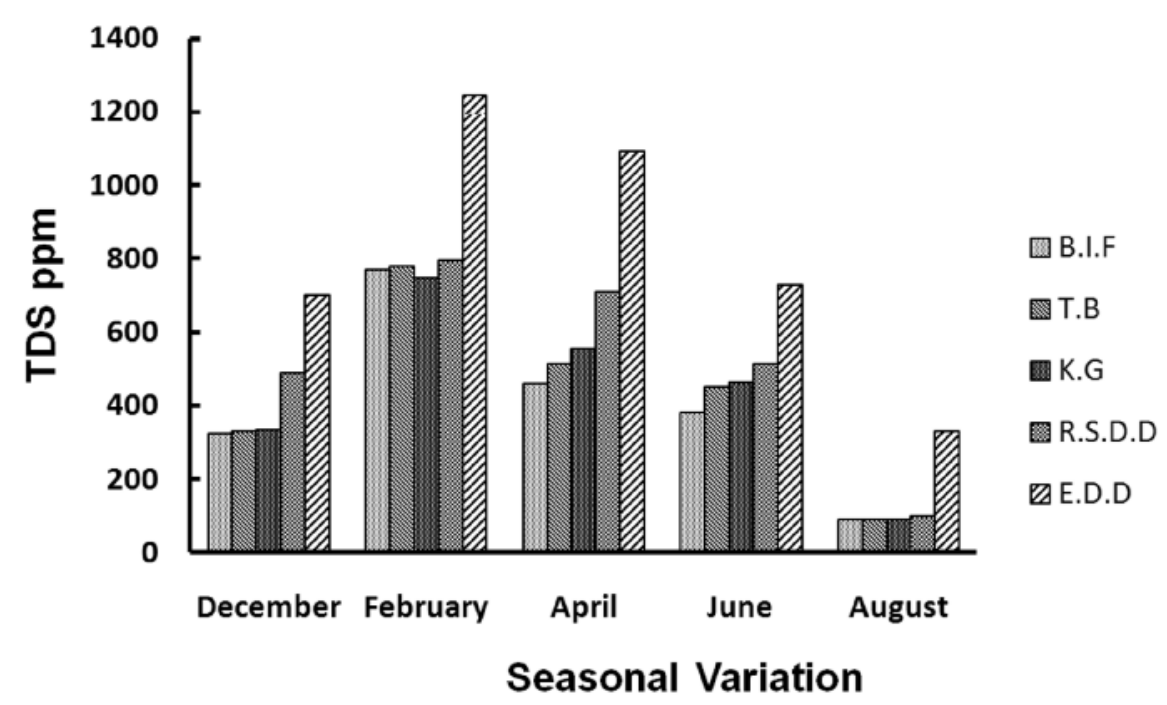

Fig. 4. Variation of TDS in the Turag river water and the Effluent of Dhaka Dying

highest value of EC in the sampling point is E.D.D (1856 $\mu \mathrm{s} / \mathrm{cm}$ ) found in February. High EC shows that a large amount of ionic substances like sodium, iron, potassium etc. which are present in industrial effluent and are usually found in textile Effluent (Kabir et al., 2002). On the other hand lowest value observed both sampling side in August. In February Salinity and TDS are increase, So EC is also increase and in August Salinity and TDS are decrease, So EC is also decrease. The correlation of EC with COD is positive and with DO it is negative. The Correlation of EC with DO and COD (P value 0.002 and 0.002 ) are significant.

\section{Dissolved oxygen (DO)}

An adequate supply of dissolve oxygen is essential for the existence of aquatic organism (Dara, 2002). Dissolved oxygen (DO) is needed for waste degradation and decomposition by microorganism. Fish in water containing excessive dissolved gases may suffer from "gas bubble disease"; however, this is a very rare occurrence. The bubbles or emboli block the flow of blood through blood vessels cause death. On the other hand, the decrease of dissolve oxygen concentration is a severe risk for aquatic life (Rahman et al., 2012).

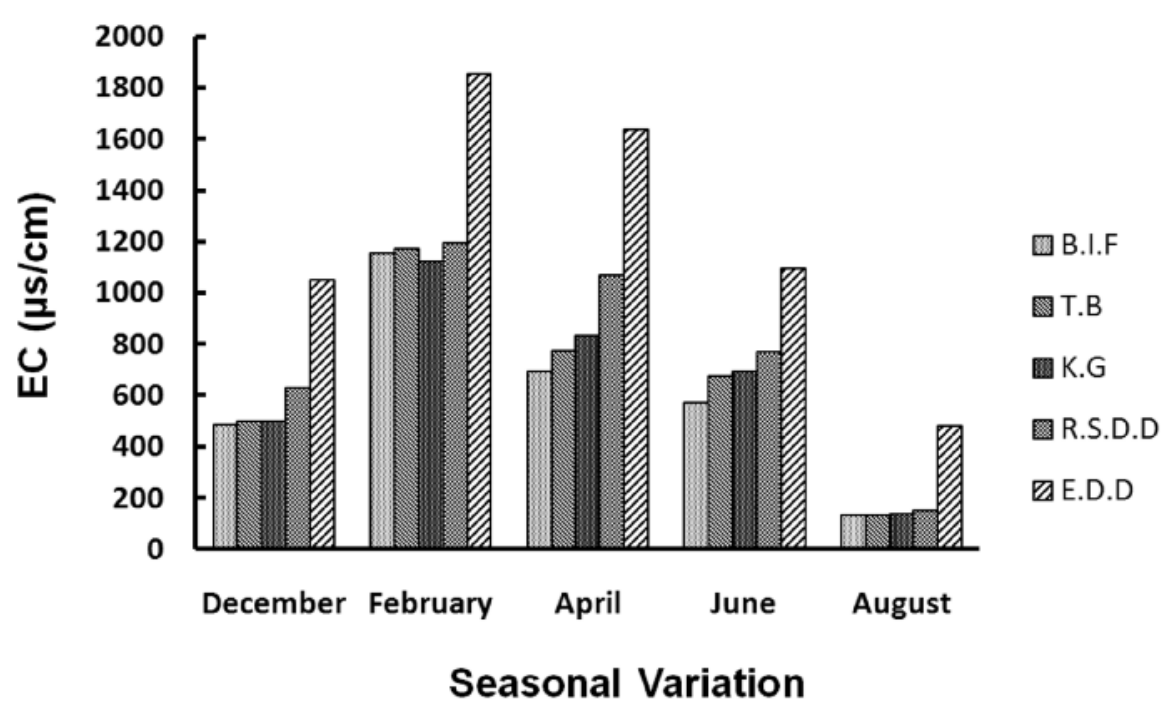

Fig. 5. Seasonal variation of EC in the Turag river water and the Effluent of Dhaka Dying 
DO values found in the range of 0.6 to $3.6 \mathrm{mg} / \mathrm{L}$ for river water and 0.5 to $3.0 \mathrm{mg} / \mathrm{L}$ for the Effluent of Dhaka dyeing shown in Fig. 6. The DO concentrations were lower in dry season and higher in rainy season. The highest value $6 \mathrm{mg} / \mathrm{L}$ for DO was found in 2006 (Rahman et al., 2012) decreased to $0.6 \mathrm{mg} / \mathrm{L}$ in the present study. This reduction is due to high discharge of organic material, e.g. from sewage treatment, storm overflows, agricultural slurry, silage liquor. Such low value do not supports the endurance of aquatic life. According to the environmental quality standard (EQS), the DO value prescribed $6 \mathrm{mg} / \mathrm{L}$ for drinking, 4 to $5 \mathrm{mg} / \mathrm{L}$ for recreation, 4 to $6 \mathrm{mg} / \mathrm{L}$ for fish and livestock and $5 \mathrm{mg} / \mathrm{L}$ for industrial application. Therefore, it can be said that Turag river water is no more suitable for any purpose. The correlation of DO with other parameters is shown in Table II. DO found negatively correlated with COD and shown ( $\mathrm{P}$ value 0.000 ) insignificant.

\section{Chemical oxygen demand (COD)}

Chemical oxygen demand (COD) is another important parameter of water quality assessment. The values of COD

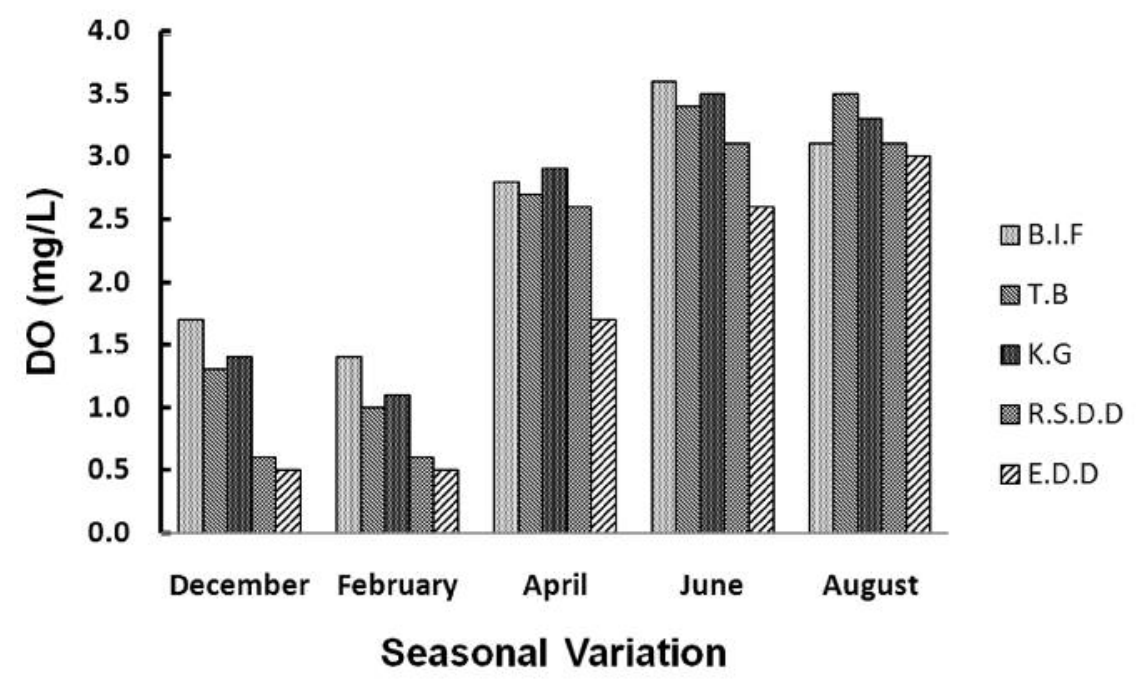

Fig. 6. Changes of DO in the Turag river water and the Effluent of Dhaka Dying

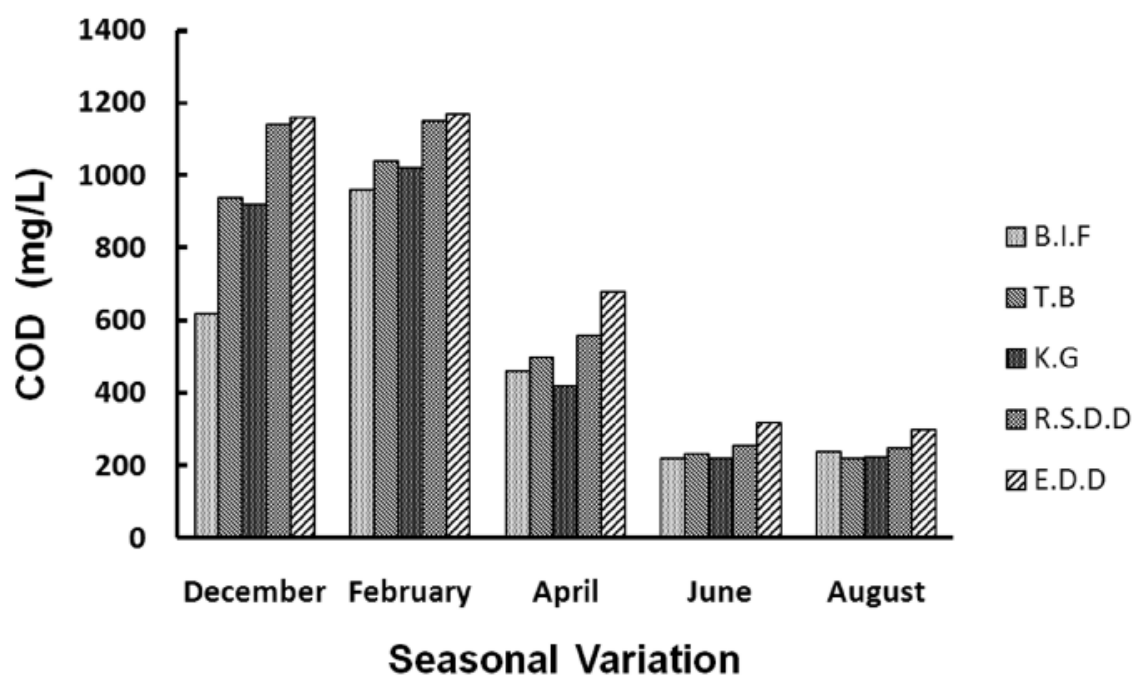

Fig. 7. COD in the Turag river water and Effluent of Dhaka Dying 


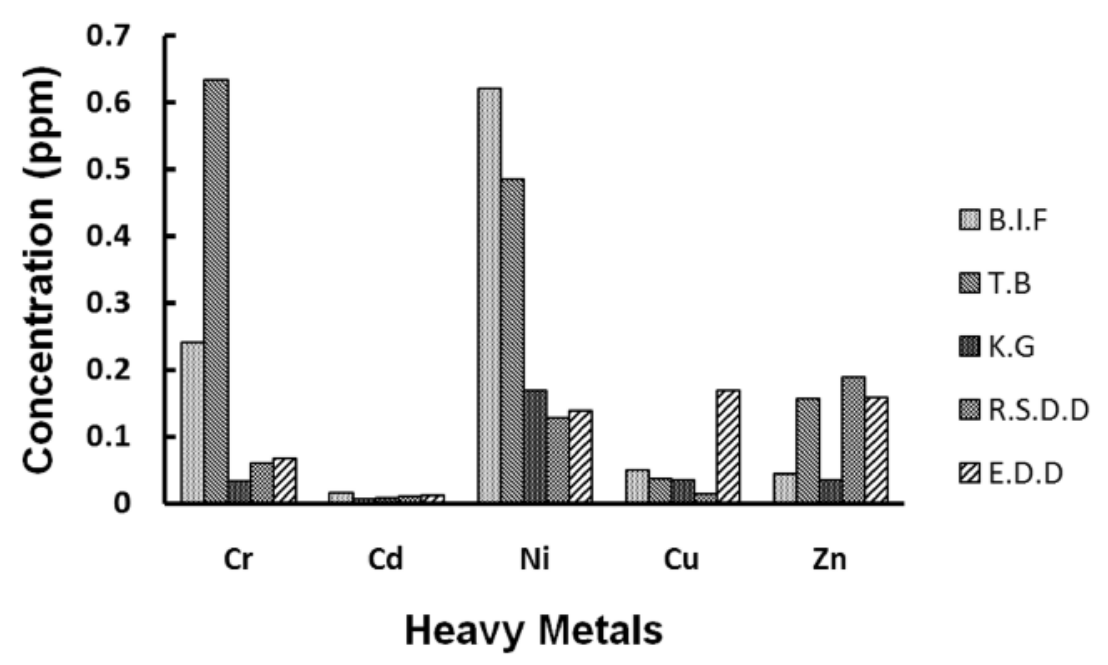

Fig. 8. Heavy metals in the Turag river water and the Effluent of Dhaka Dying

ranged from 220.00 to $1150.00 \mathrm{mg} / \mathrm{L}$ for Turag river water and 300.00 to $1170.00 \mathrm{mg} / \mathrm{L}$ for Dhaka Dying Effluent. The highest value of COD is found in February in river water and also Dhaka Dying Effluent. On the other hand lowest value of COD for both points is found during June to August. The COD effect attributed to the waste materials (organic/inorganic substances) are discharged directly into this river. The higher concentration is observed during the dry season of the year and lower concentration during the rainy season.

\section{Heavy Metal}

Presence of heavy metals in the samples are shown in Fig. 8. Drinking water standard for $\mathrm{Cr}, \mathrm{Cd}, \mathrm{Ni}, \mathrm{Cu}$ and $\mathrm{Zn}$ are 0.05, 0.01, 0.02, 2 and 5 ppm (WHO, 2003). At Bishwa Ijtema field and Tongi Bridge Heavy metals $\mathrm{Cr}$ and $\mathrm{Ni}$ are higher than other Heavy metals. In all studied points heavy metals such as $\mathrm{Cr}, \mathrm{Cd}$ and $\mathrm{Ni}$ values are higher than permissible limit but $\mathrm{Cu}$ and $\mathrm{Zn}$ are not above the permissible limit. The correlation of heavy metal is shown in Table III. Chromium

Table III Correlation chart between Heavy metal in Turag river water and Effluent of Dhaka Dying

\begin{tabular}{llllll}
\hline & $\mathrm{Cr}$ & $\mathrm{Cd}$ & $\mathrm{Ni}$ & $\mathrm{Cu}$ & $\mathrm{Zn}$ \\
\hline $\mathrm{Cr}$ & 1 & & & & \\
$\mathrm{Cd}$ & -0.453 & 1 & & & \\
$\mathrm{Ni}$ & 0.695 & 0.251 & 1 & & \\
$\mathrm{Cu}$ & -0.236 & 0.324 & -0.253 & 1 & \\
$\mathrm{Zn}$ & 0.174 & -0.392 & -0.371 & 0.177 & 1 \\
\hline
\end{tabular}

with $\mathrm{Cd}$ and $\mathrm{Cu}$ is negatively correlated whereas $\mathrm{Ni}$ and $\mathrm{Zn}$ are positively correlated. The correlation of $\mathrm{Cr}$ with $\mathrm{Cd}, \mathrm{Ni}$, $\mathrm{Cu}$ and $\mathrm{Zn}$ (P value 0.444, 0.193, 0.703 and 0.779) are shown insignificant. On the other hands correlation of $\mathrm{Cd}$ with $\mathrm{Ni}$ and $\mathrm{Cu}$ are positively correlated whereas $\mathrm{Zn}$ is negatively correlated. The correlation of $\mathrm{Cd}$ with $\mathrm{Ni}, \mathrm{Cu}$ and $\mathrm{Zn}(\mathrm{P}$ value $0.683,0.594$ and 0.514 ) are shown insignificant. Correlation of $\mathrm{Ni}$ with $\mathrm{Zn}$ and $\mathrm{Cu}$ are negatively correlated and ( $p$ value 0.539 and 0.681 ) insignificant. Correlation of $\mathrm{Cu}$ and $\mathrm{Zn}$ are positively correlated and ( $\mathrm{P}$ value 0.775 ) insignificant.

\section{Conclusion}

Almost all physicochemical parameters were found above the danger level. Some essential parameters such as DO was severely low and accordingly COD was found very high at River side of Dhaka Dying points for Turag river water and Effluent of Dhaka Dying points for Effluent during December, 2012 to February, 2013 which is completely unfavorable for aquatic life. During February, 2013 River side of Dhaka Dying showed the high value of salinity, TDS and EC as 585 ppm, 795 ppm and $1194 \mu \mathrm{s} / \mathrm{cm}$ respectively. At the same time Effluent of Dhaka Dying showed 933 ppm, $1244 \mathrm{ppm}$ and $1856 \mu \mathrm{s} / \mathrm{cm}$ respectively. Bishwa Ijtema Field and Tongi Brize highly polluted by $\mathrm{Cr}$ as $0.2408 \mathrm{ppm}$ and $0.6334 \mathrm{ppm}$ respectively but all the points (Bishwa Ijtema Field, Tongi Brize, Kachari Ghate, River side of Dhaka 
Dying and Effluent of Dhaka Dying) are polluted by Ni as 0.6207 ppm, 0.4864 ppm, 0.1697 ppm, $0.1282 \mathrm{ppm}$ and 0.1399 ppm respectively during dry season, 2013. Different types of metal industries and other industries are responsible for high value of EC, salinity, TDS and heavy metal. Effluent of Dhaka Dying is not only responsible for the source of heavy metal rather it supply from other industries. Therefore, it can be concluded that the pollution of Turag water reached at a critical point. In order to decrease pollution from various sources, appropriate action must be taken immediately. However, to protect the ecology and environment as a whole of the study area following attempts should be taken by the concern authority: (i) establish a pollution free technology such as Effluent Treatment Plants (ETP) at every industry, (ii) to avoid any kinds of pollution, consciousness is needed, so people should be aware to their work and increase awareness among industrialists about the pollution problem and their legal and social responsibility to prevent it.

\section{Acknowledgement}

We gratefully acknowledge for the laboratory and other support from the Inorganic Research Laboratory, Department of Chemistry Jagannath University and Wazed Miah Science Research Center, Jahangirnagar University.

\section{References}

Fakayode SO (2005), Impact of industrial effluents on water quality of the receiving Alaro River in Ibadan, Nigeria. Ajeam-Ragee, 10:1-13.

Satter MA and Islam MS (2005), Quality assessment of river water around Dhaka city, Bangladesh Journal of Environmental Science, 10: 326-329.

Islam JB, Sarkar M, Rahman AKML and Ahmed KS (2015), Quantitative assessment of toxicity in the Shitalakkhya River, Bangladesh. Egypt Journal of Aquatic Research, 41: $25-30$.

Madhuri U, Srinivas T and Sirresha KA (2004), Study on ground water quality in commercial area of Visakhapatnam, Poll. Res. 23(3): 565-568.
Balasankar T and Nagarajan S (2000), A correlation study on physico-chemical characteristics of ground water in and around Cuddalore Sipcot, Tamil Nadu. Indian J. Env. Prot. 20(6): 427-429.

Haigh MJ (2004), Sustainable Management of headwater Resources: The Nairobi Headwater Declaration (2002) and Beyond, Asian J. Water, Environ. Pollut. 1(1-2): $17-28$

Sarkar M, Rahman AKML, Islam JB, Ahmed KS, Uddin MN and Bhoumik NC (2015), Study of hydrochemistry and pollution status of the Buriganga River, Bangladesh. Bangladesh Journal Scientific Industrial Research, 50(2):123-134.

Karn SK and Harada H (2001), Surface water pollution in three Urban Territories of Nepal, India, and Bangladesh. Environ. Manage. 28(4): 438-496.

Department of Environment.: Water Quality Data of Rivers Buriganga, Meghna, Balu, Shitalakhya, Jamuna (19912000), Department of Environment, Dhaka (1997).

Rajdhani Unnayan Kartripakkha: Preparation of Detailed Area Plan (DAP) for DMDP: Group A. Dhaka, Bangladesh: Government of the People's Republic of Bangladesh, Ministry of Housing and Public Works, 61 (2010).

Rahman AKML, Islam M, Hossain MZ and Ahsan MA (2012), Study of the seasonal variations in Turag river water quality parameters, African Journal of Pure and Applied Chemistry, 6(10): 144-148.

ACME (2004), Water: A millennial priority. The Acme Agrovat and Beverage Ltd. Bangladesh.

Ghrefat $\mathrm{H}$ and Yusuf N (2006), Assessing Mn, Fe, Cu, Zn and Cd Pollution in Bottom Sediments of Wadi AlArab Dam, Jordan. Chemosphere, 65(11): 2114-212.

Batteiro ACR, Nishizaki H, Okubo K, Aoyma I and Mori IC (2010), Journal of Environmental Biotechnology, 4: 471-475. 
Ahipathi MV and Puttaiah ET (2006), Ecological Characteristics of Vrishabhavathi River in Bangalore (India), Environmental Geology, 49: 1217-1222.

Clesceri LS, Green berg AE and Eaton AB (1998), Standard Methods for the Examination of water and waste water, 20th edition, jointly published by American Public Health Association, American Water Works Association and Water Environment Federation.

Kabir ES, Kabir M, Islam SM, Mia CM, Begum N, Chowdhury DA, Sultana SM and Rahman SM (2002), Assessment of effluent quality of Dhaka export processing zone with special emphasis to the textile and Dying industries. Jahangirnagar Uni. J. Sci., 137-138.
Kambole MS (2003), Managing the Water Quality of the Kafue River, In: Physics and Chemistry of the Earth, Parts A/B/C, 28(20-27): 1105-1109.

Dara SS (2002), A text Book of environmental Chemistry and pollution Control. S. Chand and Company Limited, New Delhi, 2002, pp 216.

World Health Organization: Malathion in drinking water, Background Document for preparation of WHO Guidelines for drinking water Quality, World Health Organization (WHO/SDE/ WSH/03.04/103), 2003.

Received: 29 October 2015; Revised: 21 December 2015; Accepted: 31 January 2016. 